F. Reprod. Fert. (1966) 12, 225-227

BRIEF COMMUNICATION

\title{
INHIBITION OF FERTILITY IN RATS AND HAMSTERS BY STEROID IMPLANTS
}

\author{
FRED A. KINGL, A. FOLCH PI AND A. ORIOL \\ Syntex Research Center, Palo Alto, California, and \\ Escuela de Medicina Rural, I.N.P., Mexico, D.F.
}

(Received 29th December 1965)

\begin{abstract}
Summary. We have recently reported that 19-norprogesterone pellets implanted into adult mice inhibit fertility (Folch Pi, Oriol, Herrera Lasso, Maqueo, Dorfman \& Kincl, 1965). The amount of the active substance, released from the steroid-cholesterol preparation was shown to be about $10 \mu \mathrm{g} /$ day. Such low amounts were apparently not sufficient to inhibit hypothalamo-hypophysial function and fertility control was achieved by other mechanisms.

The present studies were undertaken with the purpose of establishing whether similar control of fertility could be achieved in rats and hamsters by pellet implants.
\end{abstract}

The rats used were either Wistar or Sprague-Dawley strain. Circular, flat pellets $(6 \times 1.1 \mathrm{~mm})$ weighing about $30 \mathrm{mg}$ were implanted at separate sites in the dorsal region during pro-oestrus. Control animals were either sham-operated, or were implanted with cholesterol pellets. Two days after implantation each female was caged with two males and allowed to remain for 20 days. The females were removed and allowed to deliver their young at which time the females and young were killed and autopsied; the young were counted and weighed and the sex was determined. Non-pregnant females were autopsied 10 days after all pregnant rats had delivered their young. Adult female ovaries were weighed and corpora lutea were counted, uteri were examined for implantation and resorption sites. Hamsters were treated in a similar way to the rats.

Inhibition of fertility in rats with one to four implanted pellets of varying concentration of 19-norprogesterone is shown in Table 1.

Females implanted with pellets containing $20 \%$ of 19-norprogesterone and $80 \%$ cholesterol were all infertile, due apparently to inhibition of pituitary function. The ovaries were small and usually contained only few small and growing follicles. Only in the last group were there five of seven animals which had ovaries with corpora lutea. These, however, were small and few in number. In addition, females implanted with four $10 \%$ pellets had atrophied ovaries containing small, regressing corpora lutea. No implantation sites were noted 
in the uteri of these groups. In a few cases resorption scars were noticed in these two groups. When only two $10 \%$ pellets were used an average of $3.4 \pm 2.3$ (S.E.) normally developed young were born to the treated females as compared with $12 \cdot 0 \pm 0.3$ pups born to controls. The ovaries contained a number of welldeveloped corpora lutea and the average weight was greater than that of the controls.

Lower amounts of 19-norprogesterone inhibited neither fertility nor ovulation.

\section{TABLE 1}

INHIBITION OF FERTILITY IN ADULT FEMALE RATS BY 19-NORPROGESTERONE (NP) IMPLANTS

\begin{tabular}{|c|c|c|c|c|c|}
\hline $\begin{array}{c}\text { Percent. NP } \\
\quad / \text { pellet }\end{array}$ & $\begin{array}{l}\text { No. of } \\
\text { pellets }\end{array}$ & $\begin{array}{l}\text { Total No. } \\
\text { of rats used }\end{array}$ & $\begin{array}{c}\text { Average No. } \\
\text { of uterine implan- } \\
\text { tation sites } \pm \text { S.E. }\end{array}$ & $\begin{array}{c}\text { Average No. } \\
\text { of corpora } \\
\text { lutea } \pm \text { S.E. }\end{array}$ & $\begin{array}{c}\text { Ovarian } \\
\text { weight } \pm S . E . \\
(m g)\end{array}$ \\
\hline 0 & 0 & 17 & $12 \cdot 0 \pm 0.3$ & $13 \cdot 6 \pm 0.6$ & $74 \cdot 8 \pm 5 \cdot 5$ \\
\hline Cholesterol & 4 & 6 & $12.2 \pm 0.7$ & $13.7 \pm 1.2$ & $114.0 \pm 6 \cdot 3$ \\
\hline 20 & $\begin{array}{l}4 \\
2 \\
1\end{array}$ & $\begin{array}{l}6 \\
6 \\
6\end{array}$ & $\begin{array}{l}0.0 \pm 0.0 \\
0.0 \pm 0.0 \\
0.0 \pm 0.0\end{array}$ & $\begin{array}{l}0.0 \pm 0.0 \\
0.0 \pm 0.0 \\
\text { Several* }\end{array}$ & $\begin{array}{l}38 \cdot 2 \pm 1 \cdot 1 \\
34 \cdot 4 \pm 1 \cdot 1 \\
41 \cdot 5 \pm 5 \cdot 2\end{array}$ \\
\hline 10 & $\begin{array}{l}4 \\
2 \\
1\end{array}$ & $\begin{array}{l}12 \\
10 \\
10\end{array}$ & $\begin{array}{l}0.0 \pm 0.0 \\
3.4 \pm 2.3 \\
8 \cdot 6 \pm 1.8\end{array}$ & $\begin{aligned}> & 15.0 \\
> & 15 \cdot 0 \\
& 13.6 \pm 0.7\end{aligned}$ & $\begin{array}{r}65 \cdot 0 \pm 2 \cdot 1 \\
106 \cdot 0 \pm 7 \cdot 4 \\
106 \cdot 0 \pm 5 \cdot 8\end{array}$ \\
\hline 5 & 1 & 5 & $8.6 \pm 1.7$ & $>15 \cdot 0$ & $106 \cdot 0 \pm 4 \cdot 5$ \\
\hline 1 & 1 & 6 & $9.5 \pm 0.7$ & $12 \cdot 3 \pm 0.8$ & $90 \cdot 7 \pm 6 \cdot 1$ \\
\hline
\end{tabular}

* Involuting corpora lutea.

TABle 2

INHIBITION OF FERTILITY IN ADULT FEMALE HAMSTERS BY 20\% 19-NORPROGESTERONE IMPLANTS

\begin{tabular}{c|c|c|c|c}
\hline $\begin{array}{c}\text { No. of } \\
\text { pellets }\end{array}$ & $\begin{array}{c}\text { No. of } \\
\text { animals }\end{array}$ & $\begin{array}{c}\text { Average No. } \\
\text { of uterine implan- } \\
\text { tation sites } \pm \text { S.E. }\end{array}$ & $\begin{array}{c}\text { Average No. } \\
\text { of } \\
\text { CL S.E. }\end{array}$ & $\begin{array}{c}\text { Ovarian } \\
\text { weight } \\
\text { S.E. } \pm(m g)\end{array}$ \\
\hline 0 & 6 & $10.7 \pm 0.3$ & $11.3 \pm 0.4$ & $44 \cdot 4 \pm 2 \cdot 0$ \\
4 & 6 & $0.0 \pm 0.0$ & $9 \cdot 0 \pm 1 \cdot 0$ & $21.6 \pm 3 \cdot 2$ \\
2 & 6 & $0.0 \pm 0.0$ & $8 \cdot 0 \pm 0.6$ & $23.6 \pm 2.5$ \\
1 & 6 & $0.0 \pm 0.0$ & $8 \cdot 2 \pm 1 \cdot 1$ & $19.1 \pm 1.8$ \\
\hline
\end{tabular}

In one experiment ten females were implanted with one $20 \%$ pellet for 30 days. In seven animals fertility was inhibited during the test period. Upon removal of the pellet fecundity returned within the average period of 23 days (range from 9 to 40 days). The number of offspring born was within normal limits.

The antifertility effect of 19-norprogesterone in hamsters was studied using three different concentrations (Table 2). In all groups the average number of 
observed corpora lutea was comparable to controls, but no young were born and no implantation sites were seen in any of the uteri at autopsy.

Neither rats nor hamsters have shown any other adverse effects attributable to the treatment. The average body weights showed no significant variations. Offspring born to females in the treated groups were well developed and showed no signs of malformation.

Our present data show that, in the rat, infertility induced by 19-norprogesterone implants was in most cases due to inhibition of hypothalamohypophysial function. This is supported by the observed ovarian atrophy and lack of corpora lutea formation. The presence of only few growing follicles may further indicate that the treatment interfered not only with the secretion of the luteinizing hormone but possibly also with that of follicle-stimulating hormone. There was only a narrow therapeutic range at which fertility was partially inhibited in the presence of unimpaired ovarian performance.

In the hamster 19-norprogesterone caused infertility but did not prevent the formation of corpora lutea. These effects resembled the response seen previously in mice (Folch $\mathrm{Pi}$ et al., 1965).

This method, especially if mice or hamsters are used, may be suitable for testing new compounds for blocking human fertility but not ovulation (MartinezManautou, Cortez, Giner, Aznar, Casasula \& Rudel, 1966).

\section{REFERENCES}

Folch Pi, A., Oriol, A., Herrera lasso, L., Maqueo, M., Dorfman, R. I. \& Kincl, F. A. (1965) Inhibition of fertility in mice by steroid implants. Acta endocr., Copenh. 48, 602.

Martinez-Manautou, J., Cortez, V., Giner, J., Aznar, R., Casasula, J. \& Rudel, H. W. (1966) Low doses of progestogen as an approach to fertility control. Fert. Steril. 17, 49. 